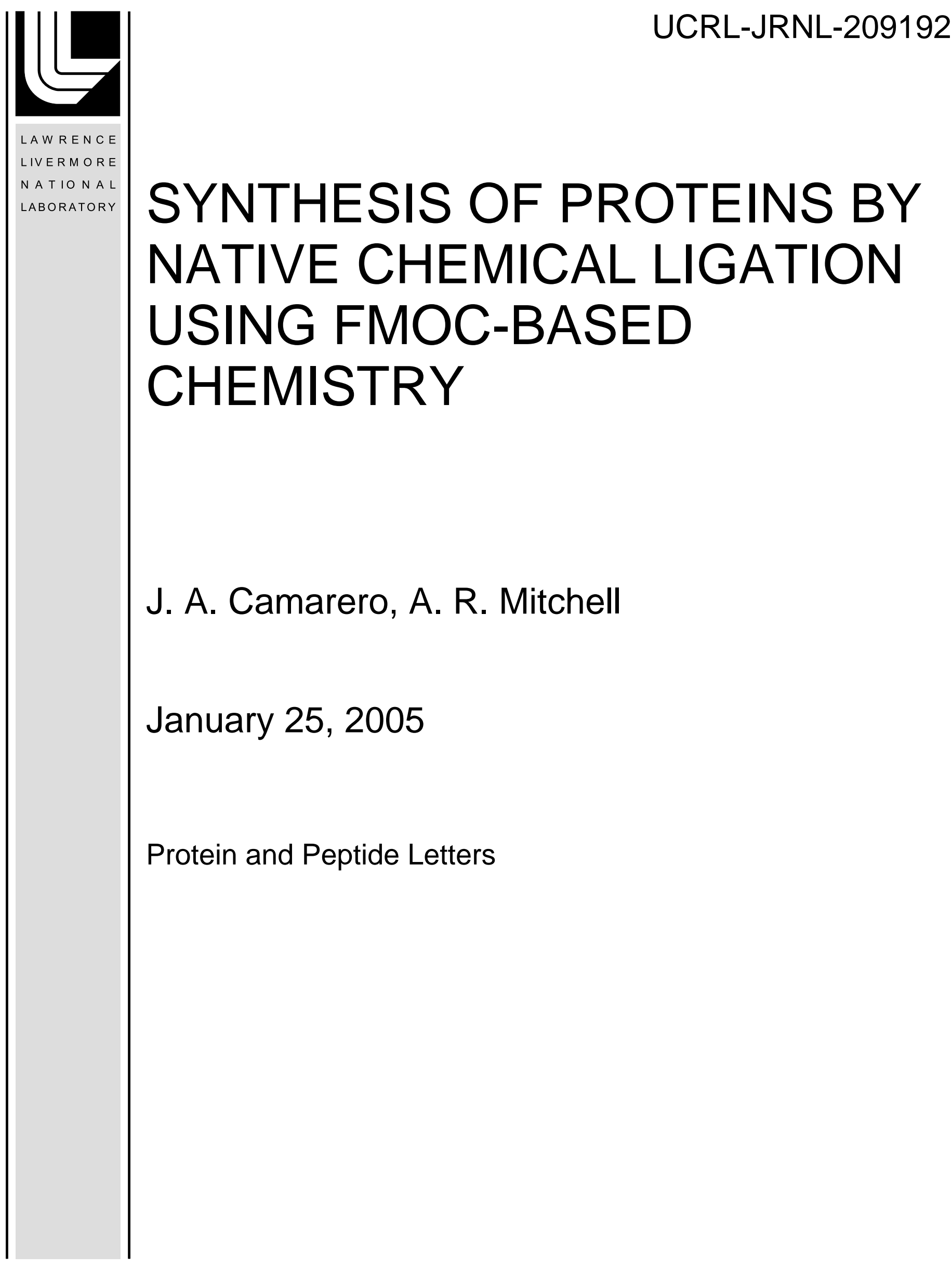


This document was prepared as an account of work sponsored by an agency of the United States Government. Neither the United States Government nor the University of California nor any of their employees, makes any warranty, express or implied, or assumes any legal liability or responsibility for the accuracy, completeness, or usefulness of any information, apparatus, product, or process disclosed, or represents that its use would not infringe privately owned rights. Reference herein to any specific commercial product, process, or service by trade name, trademark, manufacturer, or otherwise, does not necessarily constitute or imply its endorsement, recommendation, or favoring by the United States Government or the University of California. The views and opinions of authors expressed herein do not necessarily state or reflect those of the United States Government or the University of California, and shall not be used for advertising or product endorsement purposes. 


\title{
SYNTHESIS OF PROTEINS BY NATIVE CHEMICAL LIGATION USING FMOC-BASED CHEMISTRY
}

\author{
Julio A. Camarero* and Alexander R. Mitchell \\ *Chemical Biology and Nuclear Sciences Division, Lawrence Livermore National Laboratory, 7000 East \\ Avenue, Livermore, CA 94550. Tel. (925) 422 6807, e-mail: camarero1@1lnl.gov
}

\begin{abstract}
C-terminal peptide $\alpha$-thioesters are valuable intermediates in the synthesis/semisynthesis of proteins by native chemical ligation. They are prepared either by solid-phase peptide synthesis (SPPS) or biosynthetically by protein splicing techniques. The present paper reviews the different methods available for the chemical synthesis of peptide $\alpha$-thioesters using Fmoc-based SPPS.
\end{abstract}

Keywords: chemical protein synthesis, Native Chemical Ligation, peptide $\alpha$-thioester, hydrazine linker, protein engineering, Fmoc-chemistry.

\section{Introduction}

C-terminal peptide thioesters are key intermediates for the synthesis/semisynthesis of proteins [1-3] as well as for the production of cyclic peptides [4-7] by native chemical ligation (NCL) [8, 9]. These mildly activated species can also be used for the construction of topologically [10-14] and backbone engineerd [15-18] proteins.

Peptide C-terminal thioesters can be prepared by standard solid-phase peptide synthesis (SPPS) using Boc methodology $[6,19,20]$, or for larger polypeptide domains and protein domains, using intein-based bacterial expression systems $[3,21]$. Unfortunately, the Boc methodology requires the use of HF, which is extremely toxic and not well suited for synthesis of phospho- [22, 23] and glycopeptides [24-26].

The Fmoc-based methodology, on the other hand, is an attractive alternative as it does not employ HF and hence provides access to the synthesis of phospho- and glycopeptides in good yields. However, the poor stability of the thioester functionality to strong nucleophiles such as piperidine, which are used for the deprotection of the $\mathrm{N}^{\alpha}$-Fmoc group, seriously limits the use of this methodology.

In order to overcome this limitation different approaches have been described. This paper will review them in detail and will discuss their potential advantages as well as limitations. 


\section{Fmoc-based synthesis of peptide a-thioesters}

Solution synthesis using partially protected peptides. The first attempt to synthesize peptide a-thioesters using Fmoc-based SPPS was reported by Futaki et al [27]. In this approach, the corresponding peptide $\alpha$-thioesters were prepared in solution using a partially protected precursor. The protected peptide precursor was assembled on a 4-chlorotrityl (4-Cl-Trt) resin using standard Fmoc-SPPS. After cleavage from the acid-labile resin with AcOH:trifluoroethanol (TFE):dichloromethane DCM (1:1:8) at room temperature for 1 hour, the C-terminal carboxylic group of the partially protected peptide was thioesterified with the appropriate thiol using different carbodiimides in the presence of 1-hydroxybenzotriazole (HOBt) in dimethylformamide (DMF). Treatment of the product with trifluoroacetic acid (TFA) provided the fully unprotected peptide. This approach was used to generate two different 20-mer peptide thioesters derived from the transmembrane S4 segment of the rabbit skeletal muscle calcium channel and from Alamethicin in moderate yield (16\% to 20\%). Since then, Futaki's approach has been successfully used by different groups for the synthesis of different Cholecystokinin (CCK) isoforms [28], N-terminal modified Histones [29], pro-neuropeptide Y fragments [30] and several polyglycosylated polypeptides [31]. In all cases the peptide thioester fragments involved in the chemical synthesis of the different proteins were generated by Fmoc-based SPPS on a 4-Cl-Trt resin with similar yields to those reported previously. It is important to note, however, that a major drawback to this method, besides the poor solubility of protected peptides, is epimerization of C-terminal residues other than Gly during the thioesterification reaction. A recent study [30] has shown that epimerization strongly depends on the conditions as well as the coupling reagent used. The best results were obtained using phosphonium salts which only gave $\approx 2 \%$ epimerization at the C-terminal amino acid.

Solid-phase synthesis using Fmoc- $N^{\alpha}$ deprotection compatible with a-thioesters. Fmoc-deprotection cocktails designed to minimize thioester aminolysis have also been exploited for the Fmoc-based synthesis of peptide thioesters. Thus, Li et al. [32] explored various combinations of amines that could efficiently deprotect the $\mathrm{N}^{\alpha}$ Fmoc group with minimal aminolysis of the peptide thioester group. It was found that a solution of $2 \%$ hexamethylene imine, 2\% 1-hydroxybenzotriazole (HOBt) and 25\% 1-methylpyrrolidine in Nmethylpyrrolydone (NMP):dimethylsulfoxide (DMSO) (1:1) removed the $\mathrm{N}^{\alpha}$-Fmoc protecting group of a model hexapeptide thioester in $20 \mathrm{~min}$ at room temperature. Under these conditions only $15 \%$ of the peptide thioester was decomposed by aminolysis. It was also found that S-tertiary alkyl thioesters were slightly more stable to aminolysis than S-primary alkyl thioesters. Using this approach a 25-mer peptide thioester was assembled on a Fmoc-Gly-SC $\left(\mathrm{CH}_{3}\right)_{2} \mathrm{CH}_{2} \mathrm{CONH}-\mathrm{SAL}-\beta$-Ala-MBHA resin [33]. After TFA cleavage, the corresponding peptide thioester was obtained in 19\% yield. A similar approach has also been used by Hojo et al. [34] for the preparation of a 25-mer N-glycosylated peptide thioester that was later used to prepare a N-glycosylated Ig domain. Hasegawa et al. [35] have also reported the synthesis of a phosphopeptide thioester derived from the p21Max protein using this approach. In this case, however, 5\% epimerization of the C-terminal residue was 
observed during the Fmoc-based synthesis. This was attributed to the $\mathrm{N}^{\alpha}$-Fmoc deblocking solution employed during the synthesis. Epimerization was effectively suppressed, however, by shortening the time of deblocking process via the use of highly base sensitive Fmoc(2-F) groups for the $\alpha$-amino protection.

In a similar fashion, Clippingdale et al. [36] reported the synthesis of a 10-mer peptide thioester using the nonnucleophilic base 1,8-diaza-bicyclo[5.4.0] undec-7-ene (DBU) in combination with HOBt in DMF for the deprotection of the $\mathrm{N}^{\alpha}$-Fmoc during SPPS assembly. This peptide thioester was obtained in $20 \%$ yield and was used for the synthesis by NCL of a modified human $\alpha$-Synuclein. The major problem associated with this approach was aspartimide formation during DBU treatment. The use of HOBt during the deprotection step as well as backbone amide protection for the aspartimide prone sequence (Asp-Gly) considerably attenuated the formation of this by-product.

Nevertheless, the major problem associated with this strategy is the residual lability of the thioester group towards these $\mathrm{N}^{\alpha}$-Fmoc deblocking cocktails. It has been estimated that during the first and second couplings as much as $70-80 \%$ of the peptide can be lost during the removal of the Fmoc group. Surprisingly, no significant peptide loss is observed after the introduction of the third residue [35].

Solid-phase synthesis using a Backbone Amide Linker (BAL). Alsina et al. [37] reported the introduction of the $\alpha$-thioester group at the end of the synthesis of the target peptide. Key to their approach was the use of the backbone amide linker (BAL) [38, 39] which was employed to generate medium sized peptide thioesters using an Fmoc-based strategy. This strategy (Scheme 1A) relies on anchoring the growing peptide through a backbone nitrogen instead of through a terminal $C^{\alpha}$-carboxyl group [38]. Thus, the $C^{\alpha}$-carboxyl group remains protected (usually as an allyl ester) during the SPPS assembly of the peptide. Once the synthesis is completed, the $C^{\alpha}$-carboxyl protecting group is selectively deprotected and then thioesterified with the appropriate thiol. Initial studies showed, however, that direct thioesterification of the activated peptide $\mathrm{C}^{\alpha}$-carboxyl group led to significant epimerization of C-terminal residues other than Gly. This problem was minimized by reacting the activated carboxylic group with a preformed amino acid thioester residue [37]. Under these conditions epimerization of the penultimate residue was reduced to $2 \%$. The BAL approach has also been recently employed by Tulla-Puche et al. to generate circular peptides [40] and proteins [41] through intramolecular NCL $[4-7,10]$ of the corresponding $\mathrm{N}$-terminal Cys-containing peptide $\alpha$-thioesters which were assembled by Fmoc chemistry.

The main limitations of this creative approach, however, are the residual epimerization observed at the penultimate residue and (DKP) formation during the coupling of the second amino acid. Brask et al. [42] have recently reported a BAL-based approach that overcomes DKP formation. The key element in their strategy is anchoring of an amino trithioortho ester derived from Gly through a BAL support (Scheme 1B). Because trithioortho esters are not susceptible to nucleophilic attack, the formation of DKP at the dipeptide stage is totally avoided. After standard Fmoc-based assembly of the peptide, the treatment of the peptide resin with TFA 
yields directly the corresponding thioester peptide. This approach has been only applied to peptides containing a C-terminal Gly residue. Further studies are needed to determine if this strategy can be extended to chiral amino acids at this position without racemization.

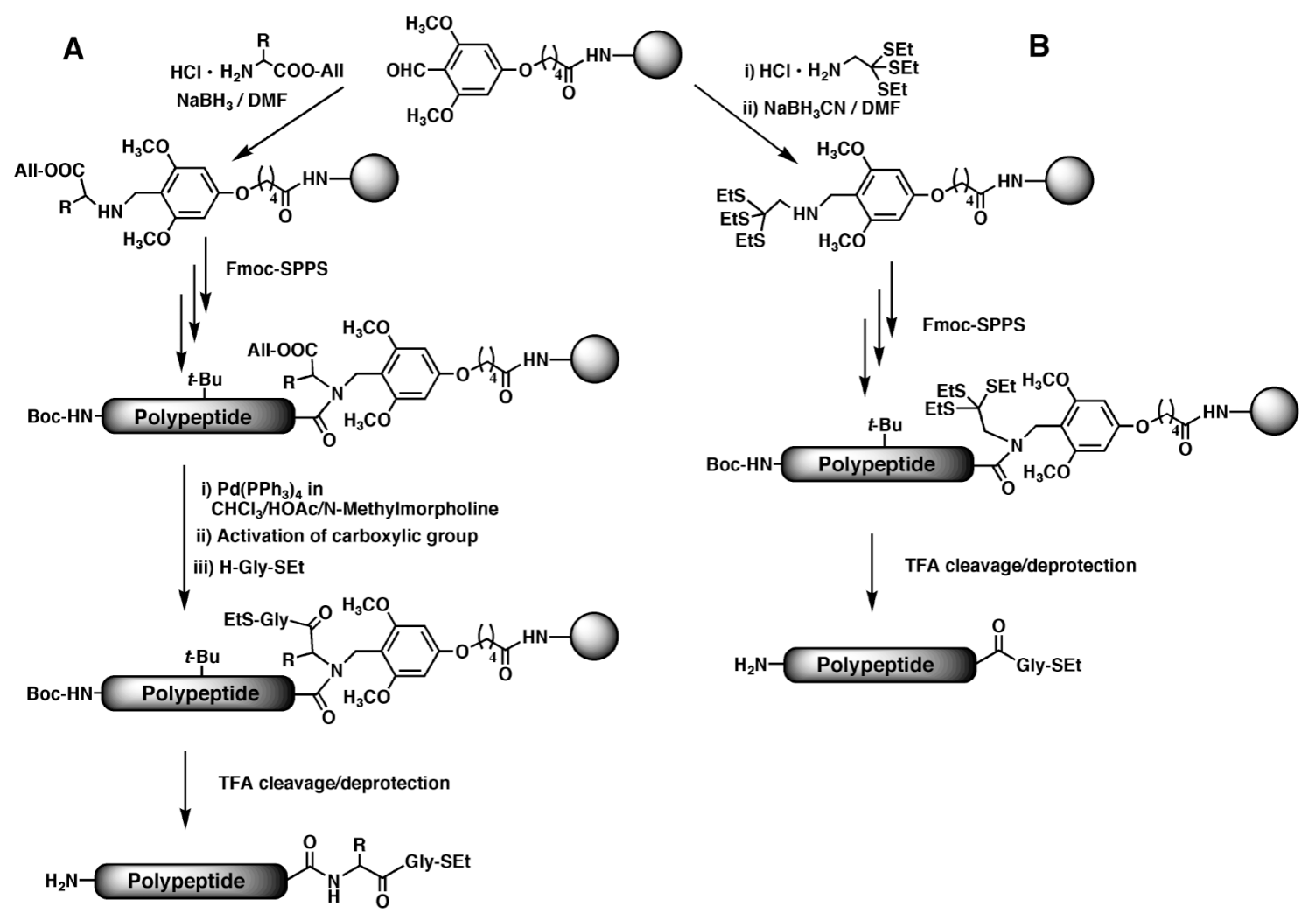

Scheme 1. Synthesis of a C-terminal Gly-containing peptide $\alpha$-thioester using the BAL linker.

Solid-phase synthesis using PAM/Wang resins and alkylaluminum-mediated thiolysis. This alternative Fmoccompatible approach for the production of peptide $\alpha$-thioesters was first reported by Swinnen et al. [43]. This synthetic scheme involves the assembly of the target peptide in either a PAM or Wang resin using standard Fmoc-based SPPS and then cleavage of the protected peptide resin with an excess of $\mathrm{AlMeCl}_{2}$ and EtSH in DCM. This process cleaves the peptide from the resin at the same time that introduces a $\mathrm{C}^{\alpha}$-thioester group at the C-terminal residue. Final TFA treatment of the protected peptide $\alpha$-thioester cleaves the side chain protecting groups. This approach was used to generate different peptide $\alpha$-thioesters in different yields, ranging from 20-60\%. However, some problems arising from epimerization of C-terminal residues other than Gly and undesired reactions, especially formation of side chain thioesters and aspartimide rearrangement, were also observed [43]. Further studies have shown that by using $\mathrm{AlMe}_{3}$ in place of the more acidic $\mathrm{AlMeCl}_{2}$, the formation of aspartimides and aspartic acid side chain thioesters can be greatly suppressed [25, 44]. However, although $\mathrm{AlMe}_{3}$ has been shown to be compatible with peptides of complex composition, earlier studies have suggested that the extent of epimerization of susceptible C-terminal thioesters would also increase. This difficulty can be circumvented when a C-terminal Gly thioester can be used. This improved approach was demonstrated by the synthesis of a C-terminal Gly-containing peptide thioester corresponding to the 37 amino 
acid long N-terminal fragment of the bovine pancreatic trypsin inhibitor [44]. This fragment was obtained in overall $8 \%$ yield, which can be compared with the $15 \%$ yield for the same peptide obtained by the Boc method. Solid-phase sythesis using Kenner's sulfonamide safety-catch linker. Ingenito et al. [45] and Shin et al. [24] independently reported in 1999 the Fmoc-based SPPS of C-terminal thioesters using Kenner's acyl-sulfonamide safety catch linker [46] as modified by Backes et al. [47, 48]. This acyl-sulfonamide linker is completely stable to basic or strongly nucleophilic conditions and can be activated by treatment with either trimethylsilyldiazomethane (TMS- $\mathrm{CHN}_{2}$ ) or iodoacetonitrile to provide a $\mathrm{N}$-alkyl acylsulfonamide, which is susceptible to nucleophilic attack. Activation with TMS- $\mathrm{CHN}_{2}$ gives usually better thiolysis yields [45]. The synthetic scheme to obtain peptide thioesters through this approach is illustrated in Scheme 2. Briefly, the first Fmoc-amino acid is attached to the linker-derivatized resin by using benzotriazole-1-yl-oxy-tris-pyrrolidino-phosphonium hexafluorophosphate (PyBOP)/N,N-diisopropylethylamine (DIEA) as coupling reagent in DMF at $-20^{\circ} \mathrm{C}$ for 8 $18 \mathrm{~h}$, and then the peptide is assembled using standard Fmoc protocols. Once the peptide is fully assembled, the resin is activated and then reacted with a suitable thiol. The protected peptide thioester is finally fully deprotected by treatment with TFA. This approach was successfully used to generate different peptide thioesters (from 3- to 24-mers) in yields $\approx 70 \%$ [45] and in the synthesis of a 24-mer glycopeptide thioester for the synthesis of the O-linked glycoprotein Diptericin by NCL [24]. Since its introduction in 1997, this approach has been used for several groups in the synthesis of different peptide thioesters involved in the production of

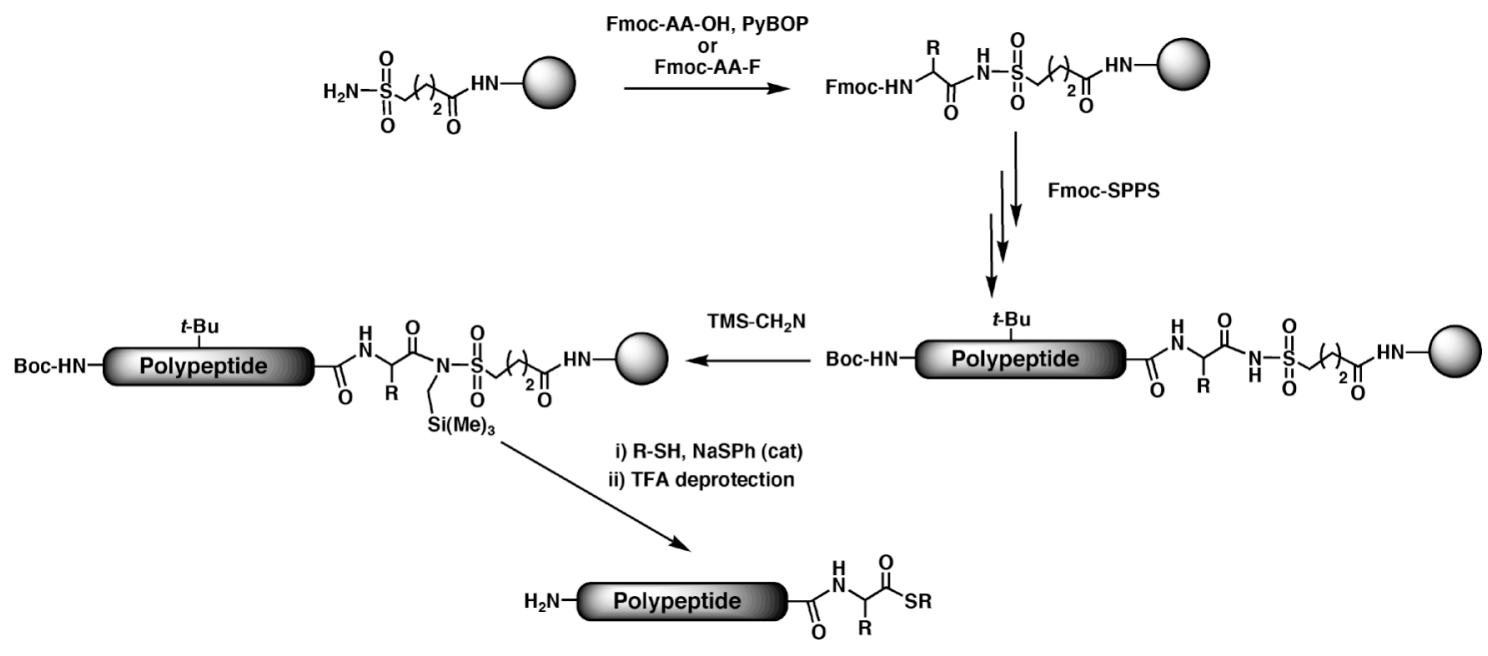

Scheme 2. Synthesis of a peptide $\alpha$-thioester using the acyl sulfonamide safety catch linker.

different glycoproteins [26], phosphoproteins [23, 49, 50], Se-containing proteins [51] and circular proteins [52] by NCL. Despite its popularity, however, this approach possesses some limitations. Several potential side reactions have described during the activation step [53], especially alkylation of Met residues. Also, the thiolmediated cleavage has been described to give inefficient or moderate cleavage yields, especially when $\beta$ branched residues are located at the C-terminus of the peptide [24, 54]. This can be improved by using TMS$\mathrm{CHN}_{2}$ as activating agent [45] and also by carrying out the thiol-mediated cleavage reaction in $2 \mathrm{M}$ LiBr/tetrahydrofuran (THF) [55]. Another difficulty associated with this approach are the long reaction times 
(8-18 h) and careful selection of reaction conditions required to obtain adequate loadings with minimal epimerization [48]. Ingenito et al. [56] have recently shown that Fmoc-amino acid fluorides (generated in situ from cyanuric fluoride [57]) are highly effective reagents for the acylation of the sulfonamide linker, enabling high loadings using short times $(\approx 90 \%$ in $1 \mathrm{~h})$ with low levels of epimerization $(<1 \%)$.

Solid-phase synthesis using an aryl hydrazine linker. Our group [58] recently reported the use of a hydrazine safety-catch linker [59-61] for the synthesis of peptide thioesters using Fmoc chemistry. The commercially available aryl hydrazine linker is totally compatible with either Fmoc- or Boc-based chemistries [62-69]. The peptide hydrazine resin, however, can be activated by treatment with mild oxidizing agents to provide a reactive acyl diazene intermediate that readily reacts with $N$ - or $O$-nucleophiles [62-67, 69-71]. This procedure (Scheme 3) involves the direct assembly of the peptide on a phenyl hydrazine resin (Novabiochem) using standard Fmoc protocols. At the end of the synthesis, the fully protected resin is activated by mild oxidation with $N$ bromosuccinimide (NBS, 2 equiv.) in the presence of pyridine (10 equiv.) in DCM for 10 min. The reactive acyl diazene is then efficiently cleaved (<30 min) with an amino acid $S$-alkyl thioester (10-20 equiv.) to yield the fully protected peptide $\alpha$-thioester. Subsequent side chain deprotection with TFA in the presence of the appropriate scavengers, provides the desired peptide thioester.

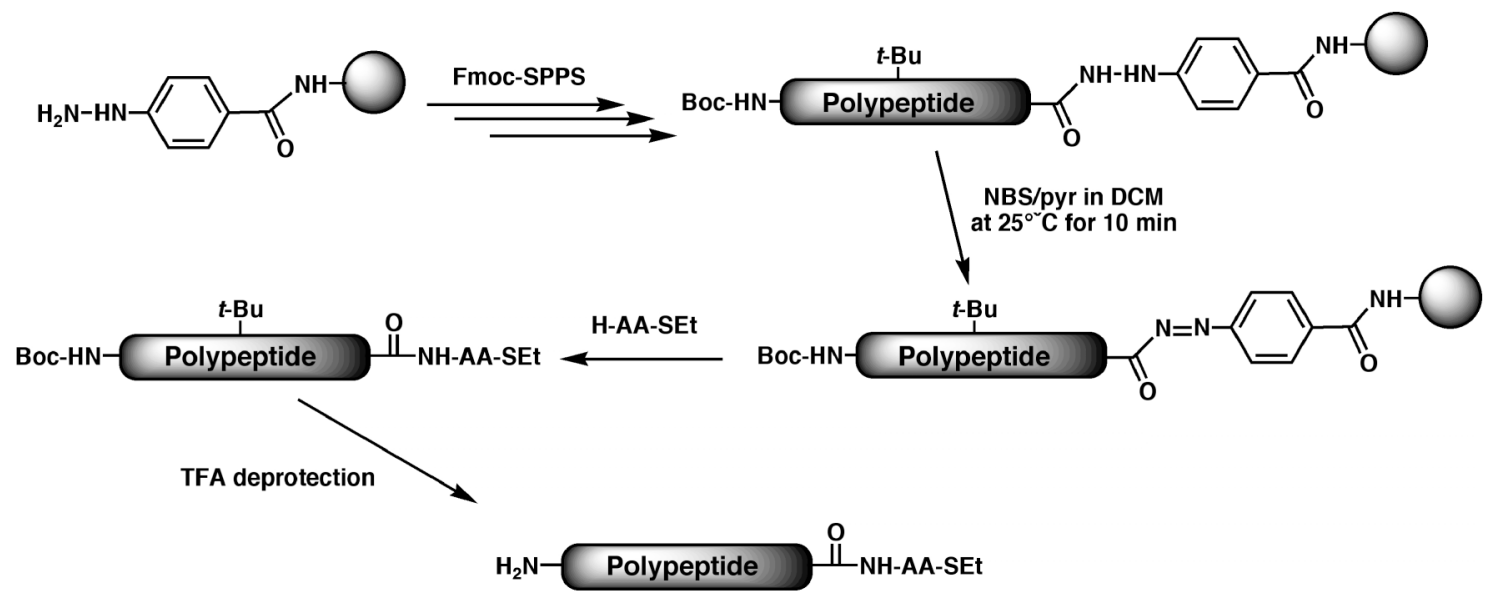

Scheme 3. Preparation of peptide $\alpha$-thioesters using an aryl hydrazine linker.

A number of model peptide thioesters were synthesized in good yields (70-90\%) using this approach [58]. No detectable racemization $(<0.5 \%)$ was observed during the activation and cleavage of the hydrazine linker [58, 69]. Also the oxidation and cleavage of peptides containing oxidative-sensitive residues (i.e. Trp, Tyr and Cys) protected as $\operatorname{Trp}\left(N^{\mathrm{im}}-\mathrm{Boc}\right), \operatorname{Tyr}(t-\mathrm{Bu})$ and $\mathrm{Cys}(\mathrm{SR})$ proceeded without side reactions under the conditions used in our study. Met-containing peptides, on the other hand, were readily oxidized to the corresponding Metsulfoxide by NBS. However, sulfoxide-Met was reduced to Met when the deprotection reaction was carried out for $3 \mathrm{~h}$ at room temperature in the presence of $2 \% \mathrm{EtSH}$ in TFA [58].

This approach was also used to generate a 13-mer $N$-terminal Cys-containing peptide thioester derived from the tenth type III module of Fibronectin [4] to generate a circular peptide by intramolecular NCL, and a 22-mer 
peptide thioester derived from the $\mathrm{N}$-terminal SH3 domain of the c-Crk protein [72] that was used to generate a fully active variant of this protein domain by NCL [58].

This approach does not require special linkers, resins or complicated protocols as commercial hydrazine resins are employed and the assembly of the peptide chain is carried out using standard SPPS methods. Amino acid Salkyl thioesters (H-Ala-SEt and H-Gly-SEt) are commercially available from Novabiochem.

\section{Summary and Conclusions}

C-terminal peptide thioesters are key intermediates for the synthesis and semisynthesis of chemically engineered and natural proteins through NCL. Peptide thioesters can be recombinantly expressed using modified protein splicing units or chemically through SPPS techniques. Boc-SPPS, which relies on the use of the highly toxic HF, has been the method of choice for the efficient preparation of peptide thioesters. The Fmocbased approach eliminates the need for HF and also provides efficient access to peptide thioesters that are either not or only partially stable to HF treatment (glyco- or phosphopeptides). In this paper we have reviewed the different methods reported in the literature that generate these valuable intermediates by Fmoc-based chemistry. All the available methods have advantages and disadvantages. Among the various methodologies reviewed, the most popular to date employs the sulfonamide linker [24, 45]. However, various problems have been associated with the use of this methodology for the production of peptide thioesters $[53,54]$. The recent introduction of the hydrazine linker for the production of peptide thioesters offers a promising alternative [58]. This linker has been successfully used for the facile preparation of peptide thioesters in good yields without limitation of size and amino acid composition. The oxidation and cleavage reactions have been shown to be totally compatible with sensitive amino acids when the appropriate protecting groups and oxidative conditions are employed.

Furthermore, no racemization is observed during the activation and cleavage of this linker.

Acknowledgments. This work was performed under the auspices of the U.S. Department of Energy by the University of California, Lawrence Livermore National Laboratory under contract No. W-7405-Eng-48.

\section{References}

[1] Dawson, P. E. and Kent, S. B. (2000) Annu. Rev. Biochem., 69, 923-960.

[2] Tam, J. P. Xu, J. X. and Eom, K. D. (2001) Biopolymers, 60, 194-205.

[3] Muir, T. W. (2003) Annu. Rev. Biochem., 72, 249-289.

[4] Camarero, J. A. and Muir, T. W. (1997) J. Chem. Soc., Chem. Comm., 1997, 1369-1370.

[5] Zhang, L. and Tam, J. P. (1997) J. Am. Chem. Soc., 119, 2363-2370.

[6] Camarero, J. A. Cotton, G. J. Adeva, A. and Muir, T. W. (1998) J. Pept. Res., 51, 303-316.

[7] Shao, Y. Lu, W. Y. and Kent, S. B. H. (1998) Tetrahedron Lett., 39, 3911-3914.

[8] Dawson, P. E. Muir, T. W. Clark-Lewis, I. and Kent, S. B. H. (1994) Science, 266, 776-779.

[9] Tam, J. P. Lu, Y. A. Liu, C. F. and Shao, J. (1995) Proc. Natl. Acad. Sci. U. S. A., 92, 12485-12489.

[10] Camarero, J. A. Pavel, J. and Muir, T. W. (1998) Angew. Chem. Int. Ed., 37, 347-349.

[11] Camarero, J. A. and Muir, T. W. (1999) J. Am. Chem. Soc., 121, 5597-5598.

[12] Iwai, H. and Pluckthum, A. (1999) FEBS Lett., 166-172.

[13] Evans, T. C. Benner, J. and Xu, M.-Q. (1999) J. Biol. Chem., 274, 3923-3926. 
[14] Camarero, J. A. Fushman, D. Sato, S. Giriat, I. Cowburn, D. Raleigh, D. P. and Muir, T. W. (2001) J. Mol. Biol., 308, 1045-1062.

[15] Lu, W. Qasim, M. A. Laskowski, M. and Kent, S. B. H. (1997) Biochemistry, 36, 673-679.

[16] Lu, W. Y. Randal, M. Kossiakoff, A. and Kent, S. B. H. (1999) Chem. Biol., 6, 419-427.

[17] Baca, M. and Kent, S. B. H. (2000) Tetrahedron, 56, 9503-9513.

[18] Yang, X. Wang, M. and Fitzgerald, M. C. (2004) Bioorg. Chem., 32, 438-449.

[19] Hojo, H. and Aimoto, S. (1991) Bull. Chem. Soc. Jpn., 64, 111-117.

[20] Camarero, J. A. Adeva, A. and Muir, T. W. (2000) Lett. Pept. Sci., 7, 17-21.

[21] Perler, F. B. and Adam, E. (2000) Curr. Opin. Biotechnol., 377-383.

[22] Muir, T. W. Sondhi, D. and Cole, P. A. (1998) Proc. Natl. Acad. Sci. U. S. A., 95, 6705-6710.

[23] Huse, M. Holford, M. N. Kuriyan, J. and Muir, T. W. (2000) J. Am. Chem. Soc., 122, 8337-8338.

[24] Shin, Y. Winans, K. A. Backes, B. J. Kent, S. B. H. Ellman, J. A. and Bertozzi, C. R. (1999) J. Am. Chem. Soc., 121, 11684-11689.

[25] Miller, J. S. Dudkin, V. Y. Lyon, G. J. Muir, T. W. and Danishefsky, S. J. (2003) Angew. Chem. Int. Ed., 42, 431-434.

[26] Macmillan, D. and Bertozzi, C. R. (2004) Angew. Chem. Int. Ed. Engl., 43, 1355-1359.

[27] Futaki, S. Sogawa, K. Maruyama, J. Asahara, T. and Niwa, M. (1997) Tetrahedron Lett., 38, 6237-6240.

[28] Kitagawa, K. Adachi, H. Sekigawa, Y. Yagami, T. Futaki, S. Gu, Y. J. and Inoue, K. (2004) Tetrahedron, 60, 907-918.

[29] Shogren-Knaak, M. A. Fry, C. J. and Peterson, C. L. (2003) J. Biol. Chem., 278, 15744-15748.

[30] von Eggelkraut-Gottanka, R. Klose, A. Beck-Sickinger, A. G. and Beyermann, M. (2003) Tetrahedron Lett., 44, 3551-3554.

[31] Warren, J. D. Miller, J. S. Keding, S. J. and Danishefsky, S. J. (2004) J Am Chem Soc, 126, 6576-6578.

[32] Li, X. Q. Kawakmi, T. and Aimoto, S. (1998) Tetrahedron Lett., 39, 8669-8672.

[33] Rink, H. (1987) Tetrahedron Lett., 28, 3787-3790.

[34] Hojo H, H. E., Matsumoto Y, Nakahara Y, Nabeshima K, Toole BP, Watanabe Y (2003) Tetrahedron Lett., 44, 2961-2964.

[35] Hasegawa, K. Sha, Y. L. Bang, J. K. Kawakami, T. Akaji, K. and Aimoto, S. (2002) Lett. Pept. Sci., 8, 277-284.

[36] Clippingdale, A. B. Barrow, C. J. and Wade, J. D. (2000) J. Pept. Sci., 6, 225-234.

[37] Alsina, J. Yokum, T. S. Albericio, F. and Barany, G. (1999) J. Org. Chem., 64, 8671-8769.

[38] Jensen, K. J. Alsina, J. Songster, M. F. Vágner, J. Albericio, F. and Barany, G. (1998) J. Am. Chem. Soc., 120, 5441-5452.

[39] Alsina, J. and Albericio, F. (2003) Biopolymers, 71, 454-477.

[40] Tulla-Puche, J. and Barany, G. (2004) J Org Chem, 69, 4101-4107.

[41] Tulla-Puche, J. Getun, I. V. Woodward, C. and Barany, G. (2004) Biochemistry, 43, 1591-1598.

[42] Brask, J. Albericio, F. and Jensen, K. J. (2003) Org. Lett., 5, 2951-2953.

[43] Swinnen, D. and Hilvert, D. (2000) Org. Lett., 2, 2439-2442.

[44] Sewing, A. and Hilvert, D. (2001) Angew. Chem. Int. Ed., 40, 3395-3396.

[45] Ingenito, R. Bianchi, E. Fattori, D. and Pessi, A. (1999) J. Am. Chem. Soc., 121, 11369-11374.

[46] Kenner, G. W. McDermott, J. R. and Sheppard, R. C. (1971) Chem. Comm., 636-637.

[47] Backes, B. J. Virgilio, A. V. and Ellman, J. A. (1996) J. Am. Chem. Soc., 118, 3055-3056.

[48] Backes, B. J. and Ellman, J. A. (1999) J. Org. Chem., 64, 2322-2330.

[49] Teruya, K. Murphy, A. C. Burlin, T. Appella, E. and Mazur, S. J. (2004) J Pept Sci, 10, 479-493.

[50] Jantz, D. and Berg, J. M. (2004) Proc Natl Acad Sci U S A, 101, 7589-7593.

[51] Gieselman, M. D. Xie, L. and van Der Donk, W. A. (2001) Org Lett, 3, 1331-1334.

[52] Deechongkit, S. and Kelly, J. W. (2002) J Am Chem Soc, 124, 4980-4986.

[53] Flavell, R. R. Huse, M. Goger, M. Trester-Zedlitz, M. Kuriyan, J. and Muir, T. W. (2002) Org Lett, 4, 165-168.

[54] Marcaurelle, L. A. Mizoue, L. S. Wilken, J. Oldham, L. Kent, S. B. Handel, T. M. and Bertozzi, C. R. (2001) Chemistry, 7, 1129-1132. 
[55] Quaderer, R. and Hilvert, D. (2001) Org. Lett., 3, 3181-3184.

[56] Ingenito, R. Dreznjak, D. Guffler, S. and Wenschuh, H. (2002) Org. Lett., 4, 1187-1188.

[57] Carpino, L. A. Sadataalaee, D. Chao, H. G. and Deselms, R. H. (1990) J. Am. Chem. Soc., 112, 96519652.

[58] Camarero, J. A. Hackel, B. J. de Yoreo, J. J. and Mitchell, A. R. (2004) J. Org. Chem., 69, 4145-4151.

[59] Wolman, Y. Gallop, P. M. and Patchornik, A. (1961) J. Am. Chem. Soc., 83, 1263-1264.

[60] Milne, H. B. and Most, C. F. (1968) J. Org. Chem., 33, 169-175.

[61] Wieland, T. Leawalter, J. and Birr, C. (1970) Liebigs Ann. Chem., 740, 31-51.

[62] Millington, C. R. Quarrell, R. and Lowe, G. (1998) Tetrahedron Lett., 39, 7201-7204.

[63] Semenov, A. N. and Gordeev, K. Y. (1995) Int. J. Peptide Protein Res., 45, 303-304.

[64] Stieber, F. Grether, U. and Waldmann, H. (1999) Angew. Chem. Int. Ed., 38, 1073-1077.

[65] Rosenbaum, C. and Waldmann, H. (2001) Tetrahedron Lett., 42, 5677-5680.

[66] Ludolph, B. and Waldmann, H. (2003) Chem. Eur. J., 9, 3683-3691.

[67] Peters, C. and Waldmann, H. (2003) J. Org. Chem., 68, 6053-6055.

[68] Kohn, M. Wacker, R. Peters, C. Schroder, H. Soulere, L. Breinbauer, R. Niemeyer, C. M. and Waldmann, H. (2003) Angew Chem Int Ed Engl, 42, 5830-5834.

[69] Kwon, Y. Welsh, K. Mitchell, A. R. and Camarero, J. A. (2004) Org. Lett., 6, 3801-3804.

[70] Berst, F. Holmes, A. B. Ladlow, M. and Murray, P. J. (2000) Tetrahedron Lett., 41, 6649-6653.

[71] Kragol, G. Lumbierres, M. Palomo, J. M. and Waldmann, H. (2004) Angew. Chem. Int. Ed. Engl., 43, 5839-5842.

[72] Camarero, J. A. Ayers, B. and Muir, T. W. (1998) Biochemistry, 37, 7487-7495. 